Gıda Mühendisliği / Food Engineering

DOI: 10.21597/jist.741326 Araştırma Makalesi / Research Article

Geliş tarihi / Received: 22-05-2020

Kabul tarihi / Accepted: 30-10-2020

\title{
The Effect of Sodium Caseinate or Chitosan Edible Coatings on Some Chemical Textural and Microbiological Characteristics of Kashar Cheese
}

\author{
Ümit YALÇIN ${ }^{1}$, Seval ANDİÇ ${ }^{1 *}$, Suna AKKOL ${ }^{2}$
}

\begin{abstract}
This study aimed to evaluate the effects of the edible coatings produced from casein, casein / transglutaminase enzyme, and chitosan on certain chemical, textural, and microbiological properties of Kashar cheese over a storage period of 60 days. The use of edible coatings affected the levels of nitrogen fractions (water-soluble nitrogen, trichloroacetic acid-soluble nitrogen, and phosphotungstic acid-soluble nitrogen) and the lipolysis level of Kashar cheese to a statistically significant extent ( $\mathrm{P}<0.05$ for all). The levels of nitrogen fractions and lipolysis in the uncoated control group cheeses increased significantly $(\mathrm{P}<0.05)$ during the storage period compared to coated cheese. Cheese samples coated with chitosan yielded significantly lower yeast-mould counts compared to samples that were uncoated or coated with sodium caseinate or sodium caseinate/transglutaminase at the end of the storage period $(\mathrm{P}<0.05)$. The results indicated that the edible coatings had a significant effect on the chemical, textural, and microbiological properties of Kashar cheese.
\end{abstract}

Keywords: Edible film, Kashar cheese, chitosan, transglutaminase, sodium caseinate

\section{Sodyum Kazeinat veya Kitosan Bazlı Yenilebilir Kaplamaların Kaşar Peynirnin Bazı Kimyasal, Yapısal ve Mikrobiyolojik, Özelliklerine Etkisi}

ÖZET: Çalışmada sodyum kazeinat, sodyum kazeinat / transglutaminaz enzimi ve kitosandan üretilen yenilebilir kaplamaların, 60 günlük depolama süresinde Kaşar peynirinin bazı, kimyasal, yapısal ve mikrobiyolojik özellikleri üzerine etkisi araştırılmıştır. Yenilebilir kaplamalar Kaşar peynirinin azot fraksiyonları (suda çözünür azot, trikloroasetik asitte çözünür azot ve fosfotungustik asitte çözünür azot) ve lipoliz düzeylerini istatistiki olarak önemli $(\mathrm{P}<0.05)$ düzeyde etkilemiştir. Kaplanmamış kontrol grubu peynir örneklerinin azot fraksiyonları ve lipoliz düzeyleri depolama süresi boyunca kaplanmış peynir örneklerine göre istatistiki olarak önemli $\mathrm{P}<0.05$ ) düzeyde artmıştır. Depolama sonunda kitosanla kaplanan peynir örneklerinin küf-maya sayılarının kaplanmamış, sodyum kazeinat veya sodyum kazeinat/transglutaminaz ile kaplanmış peynir örneklerinin küf-maya sayılarından önemli $(\mathrm{P}<0.05)$ düzeyde düşük olduğu tespit edilmiştir. Çalışma sonuçları kullanılan yenilebilir kaplamaların Kaşar peynirinin incelenen kimyasal, yapısal ve mikrobiyolojik özellikleri üzerinde önemli düzeyde etkili olduğunu göstermiştir.

Anahtar Kelimeler: Yenilebilir film, Kaşar peyniri, kitosan, transglutaminaz, sodyum kazeinat

${ }^{1}$ Ümit Yalçın (Orcid ID: 0000-0002-4693-4234), Seval ANDİÇ (Orcid ID: 0000-0002-8306-0222), Van Yüzüncü Y1l University, Faculty of Engineering, Department of Food Engineering, Van, Turkey

${ }^{2}$ Suna AKKOL (Orcid ID: 0000-0001-5123-7516), Van Yüzüncü Y1l University, Faculty of Agriculture, Department of Animal Science, Van, Turkey

*Sorumlu Yazar/Corresponding Author: Seval Andiç, e-mail: sevalandic@yyu.edu.tr

This article was create from Ümit Yalçın's master thesis and has been presented as a poster at the Cheese Symposium held in Rennes, France 4-6 April 2018. 


\section{INTRODUCTION}

Active packaging refers to packaging systems that ensure the preservation of product quality during interactions between the environment, product, and packaging, via the introduction of certain auxiliary components to the latter. Antioxidants, antimicrobials, moisture control components, preservatives added to prevent premature ripening, and packages employing carbon dioxide release systems are all examples of active packaging elements (Suppakul et al., 2003; Özdemir and Floros, 2004; Vilela et al., 2018). The materials used in active packaging are plastic and edible films. Although plastic packaging materials are economical, their effects on the environment, food, and health are negative. Replacing plastic with alternative materials, however, increases the cost of packaging. Therefore, the search for alternative, effective, and inexpensive materials to replace plastic continues apace, with the trend towards edible films and coatings gaining traction in recent years. Edible films and coatings are obtained from polysaccharides, lipids, or proteins and, when applied to foods, regulate moisture, gas, and solid permeability (Chen, 1995; Özdemir and Floros, 2004). Edible films and coatings primarily control the transfer of oxygen, carbon dioxide, and lipids to improve the overall quality and physical properties of food, reduce the loss of flavour and aromatic substances, and lengthen the shelf life by preserving the antioxidants, antimicrobial agents, pigments, ions, and vitamins already present in the product. They also provide mechanical protection by hampering crushing and breaking, thereby contributing to the integrity of the food (Debeaufort et al., 1998; Guillard et al., 2003). Successful results have been achieved particularly in sliced fresh fruits and vegetables, portioned or sliced cheeses, meat and meat products, and nuts in the fast-food industry (Gennadios et al., 1997; Kang et al., 2007; Sahan et al., 2008; Krasaekoopt and Mabumrung, 2008; Simôes et al., 2009; Di Pierro et al., 2011; Moreira et al., 2011; Sánchez-Ortega et al., 2014; Dhall, 2013; Valenzuela et al., 2015; Artiga-Artigas et al., 2017;).

Edible films are produced mainly from proteins, polysaccharides, and lipids. Plant-based proteins (such as corn zein, wheat gluten, soy protein, pea protein, sunflower protein, peanut protein, and cottonseed protein) and animal-based proteins (such as keratin, collagen, gelatine, fish myofibrillary protein, egg white protein, casein, and whey protein) can both be used in the production of edible films. Polysaccharide-based films are produced from biological materials such as chitosan, starch, carrageenan, pectin, and pullulan (Chen, 1995; Shahidi et al., 1999; Kaya and Kaya, 2000; Barreto et al., 2003; Devlieghere et al., 2004; Peng et al., 2005; Hassan et al., 2018).

The properties of edible films may further be modified or improved by employing a combination of proteins, polysaccharides, or lipids. Plasticizers, including sorbitol, glycerol, polyethylene glycol, and mannitol, are also used to improve the mechanical properties of edible films. The transglutaminase enzyme, in conjunction with various natural antioxidants and antimicrobial agents, bolsters the mechanical properties of edible films and their ability to prevent adverse microbial growth and chemical reactions (Mizuno et al., 1999; Kuraishi et al., 2007).

Various studies have reported decreased surface discolouration, moisture loss, respiration, microbial infection, and consequently, reduced quality losses in whole or sliced fruits and vegetables coated with edible films produced from various organic materials. Studies have also reported increased shelf life in sliced and ready-to-consume fruits and vegetables (Krasaekoopt and Mabumrung, 2008; Simôes et al., 2009; Moreira et al., 2011; Dhall, 2013; Valenzuela et al., 2015; Artiga-Artigas et al., 2017).

In some studies on cheddar, mozzarella, Kashar, and other low-fat as well as local cheeses, edible films produced from carbohydrates and proteins obtained from different sources have been successful in preventing various declines in quality due to chemical and microbiological factors (Y1ldirım et al., 
2006; Yaşar and Güzeler, 2011; Zhong et al., 2014). Coatings have also been shown to minimize the problem of oil absorption in fried products (Kürek et al., 2017; Ananey-Obiria et al., 2018).

In the present study, casein and chitosan comprised the principal materials in the production of edible films. The transglutaminase enzyme to enhance the properties of casein and sorbitol as plasticizer were used. The films produced were applied to slices of fresh Kashar cheese and chemical, microbiological, and textural changes in the cheese were observed over a 60-day storage period.

\section{MATERIALS AND METHODS}

\section{Materials}

The samples of Kashar cheese used in this study were produced from additive- and contaminantfree milk, using the classic boiling method. The sodium caseinate and transglutaminase used in film production were obtained from BENOSEN Import Company (İstanbul/Turkey), while chitosan and sorbitol were procured from ACROS ORGANICS company (Geel, Belgium). The Kashar cheeses were divided into 4 groups. Group 1 was uncoated and served as the control group. Groups 2, 3, and 4 were coated with edible films produced using sodium caseinate, a combination of sodium caseinate and transglutaminase, and chitosan, respectively. Sorbitol was used as a plasticizer in the preparation of the edible films. The prepared film solutions were cooled to room temperature, and the cheese samples, having been portioned into $100 \mathrm{~g}$, were dipped into the solution and coated. The coated cheese samples were left to dry for 24 hours at room temperature and then stored in plastic packages at $+4{ }^{\circ} \mathrm{C}$. The samples were analyzed on days 0,30 , and 60 of the storage period.

\section{Methods}

\section{Preparation of edible coatings}

The method described by Barreto et al. (2003) was used for the production of the sodium caseinatebased film. Sodium caseinate was dissolved in distilled water $(10 \% \mathrm{w} / \mathrm{v})$ and stirred in a magnetic stirrer until the mixture achieved homogeneity. The prepared solution was then heat-treated in a $75{ }^{\circ} \mathrm{C}$ water bath for 30 minutes. When phase separation occurred, plasticizer (sorbitol) was added at a rate of $40 \%$ of the amount of protein (sodium caseinate) used in the preparation of the solution. The solution was subsequently cooled to room temperature and the cheese samples were dipped into the solution for coating.

The sodium caseinate and transglutaminase enzyme-based film solutions were prepared using the method specified by Carvalho and Grosso (2004). Sodium caseinate was dissolved in distilled water $(10 \% \mathrm{w} / \mathrm{v})$ and homogenized using a magnetic stirrer. The prepared solution was heat-treated in a $75^{\circ} \mathrm{C}$ water bath for 30 minutes. Following the heat treatment, transglutaminase enzyme $\left(10 \mathrm{U} \mathrm{g}^{-1}\right)$ was added to the solution and the mixture was left at $50{ }^{\circ} \mathrm{C}$ for 15 minutes to activate the enzyme. At the end of this period, the transglutaminase enzyme was inactivated by heat treatment at $85{ }^{\circ} \mathrm{C}$ for 10 minutes. Finally, sorbitol was added to the solution at a rate of $40 \%$ of the protein amount, and after cooling to room temperature, the cheese portions were dipped into the solution and coated.

For the production of the chitosan-based film solution, the method specified by Moreira et al. (2011) was employed. Chitosan $(2 \%)$ was dissolved in $2 \%$ acetic acid at $45{ }^{\circ} \mathrm{C}$ for 30 minutes. The solution was then sterilized at $121{ }^{\circ} \mathrm{C}$ for 15 minutes and sorbitol was added at a proportion of $40 \%$ of the chitosan used. Finally, the solution was cooled to room temperature, after which the cheeses were dipped into the solution to be coated. 


\section{Chemical analysis}

Dry matter analysis of the cheese samples was performed according to International Dairy Federation (IDF) standards using the gravimetric method (IDF, 2004). The $\mathrm{pH}$ values of the samples were measured using the Orion StarTM A211 pH meter (Thermo Fisher Scientific, Waltham, MA, USA). The acidity values of the samples (lactic acid) were determined by the titration method in accordance with the Association of Official Agricultural Chemists (AOAC) standard method (AOAC, 2002a), while the total nitrogen ratios were determined using the Kjeldahl method (AOAC, 2002b). Water-soluble nitrogen (WSN), trichloroacetic acid-soluble nitrogen (TCA-SN) (non-protein nitrogen), and phosphotungstic acid-soluble nitrogen (PTA-SN) (amino nitrogen) contents of coated and uncoated Kashar cheeses were determined using a modified version of the method described by Butikofer et al. (1993).

\section{Determination of lipolysis value (ADV)}

To determine the acid degree value (ADV) of cheese samples, $10 \mathrm{~g}$ of the sample was weighed and $15 \mathrm{~mL}$ of Bureau of Dairy Industries (BDI) solution (obtained by dissolving $30 \mathrm{~g}$ of Triton X-100 and $70 \mathrm{~g}$ of sodium tetraphosphate in a 1:1 solution with distilled water) was added. The samples were shredded and placed in butyrometers, allowing the oil to be completely released into the boiling water. Sufficient aqueous methanol (1:1 water-methanol) was added to bring the oil column to the butyrometer throat and the samples were centrifuged for 5 minutes. The oil, having been released and collected in the throat of the butyrometer, was then drawn into a beaker using a syringe and weighed. Five (5) $\mathrm{mL}$ of the solvent (petroleum ether/n-propanol; $4: 1 \mathrm{v} / \mathrm{v}$ ) containing $0.1 \mathrm{~g} \mathrm{~L}^{-1}$ of thymol blue indicator was titrated with $0.01 \mathrm{~N}$ tetra n-butyl ammonium hydroxide (IDF, 1991).

\section{Texture profile analysis (TPA)}

Texture profile analyses (TPA) of the cheese samples were performed using the TA.XT2 Texture Analyzer (Stable Micro Systems, UK) with a load cell of $5 \mathrm{~kg}$. The P/0.25S-P/1S 1 spherical probe apparatus was used for the analysis. Three penetrations were made per cheese sample. Values for the hardness, springiness, cohesiveness, chewiness, and adhesiveness of the cheese samples were determined by TPA.

\section{Determination of yeast and mould counts}

Dehydrated Potato Dextrose Agar (PDA) was used the determine the yeast and mould counts of the cheese samples. The prepared medium was sterilized in an autoclave at $121^{\circ} \mathrm{C}$ for 15 minutes and its $\mathrm{pH}$ was adjusted to $3.5 \mathrm{using}$ sterile tartaric acid $(10 \% \mathrm{w} / \mathrm{v})$. Next, $15 \mathrm{~mL}$ portions were transferred to sterile Petri dishes and solidified, after which preparations from the appropriate sample dilutions were applied by the spread plate technique. Cultured media were allowed to incubate at $24{ }^{\circ} \mathrm{C}$ for $5-7$ days. Colonies formed as a result of incubation were then counted and logarithmic transformation was applied to the results of the microbiological counts.

\section{Statistical analysis}

Statistical analysis of the data was performed using the IBM SPSS Version 22 program. Analysis of variance was calculated based on the obtained values. Significant differences were evaluated using the Duncan multiple comparison test. 


\section{RESULTS AND DISCUSSION}

\section{Chemical Properties}

The results showed an increase in the dry matter values of all cheese samples proportional to storage time. The highest dry matter value was obtained from the control group samples. There was a statistically significant difference between the dry matter values of the coated samples and the dry matter values of the control group $(\mathrm{P}<0.05)$, which can be explained by the coated samples losing less moisture than the uncoated samples. Among the coated samples, the lowest dry matter content - and therefore the least moisture loss - was observed in samples from the 3rd group (those coated with sodium caseinate + transglutaminase) (Table 1). The transglutaminase (Tgaz) enzyme catalyses the isopeptide bonds between peptides or amino acids and forms cross-links to improve the functional properties of proteins, including water retention, viscosity, and emulsification (Mizuno et al., 1999; Schorsch et al., 2000; Sharma et al., 2002). In studies conducted with cheeses, edible coating materials were found to reduce moisture loss, similar to our results (Cerqueira et al., 2010; Zhong et al., 2014; Yangilar, 2015; Yang1lar and Oğuzhan-Yıldız, 2016; Embuena et al., 2017).

Table 1. Results of some chemical analysis of Kashar cheese uncoated and coated with different edible films (mean \pm standard deviation)

\begin{tabular}{|c|c|c|c|c|}
\hline & \multicolumn{4}{|c|}{ Storage Period (Days) } \\
\hline & Sample & $\mathbf{0}$ & 30 & 60 \\
\hline \multirow{4}{*}{$\begin{array}{l}\text { Dry Matter } \\
(\%)\end{array}$} & 1 & $55.90 \pm 0.15^{\mathrm{Ca}}$ & $60.82 \pm 1.05^{\mathrm{Ba}}$ & $65.58 \pm 1.49^{\mathrm{Aa}}$ \\
\hline & 2 & $56.19 \pm 0.25^{\mathrm{Ca}}$ & $59.69 \pm 0.91^{\mathrm{Ba}}$ & $63.89 \pm 0.17^{\mathrm{Aab}}$ \\
\hline & 3 & $55.82 \pm 0.27^{\mathrm{Ba}}$ & $60.73 \pm 0.75^{\text {Aa }}$ & $61.43 \pm 0.64^{\mathrm{Ab}}$ \\
\hline & 4 & $56.23 \pm 0.37 \mathrm{Ca}$ & $60.49 \pm 0.25^{\mathrm{Ba}}$ & $63.75 \pm 1.06^{\mathrm{Aab}}$ \\
\hline \multirow{4}{*}{ Titratable Acidity (\%) } & 1 & $0.79 \pm 0.06^{\mathrm{Ca}}$ & $1.10 \pm 0.05^{\mathrm{Ba}}$ & $3.33 \pm 0.05^{\mathrm{Aa}}$ \\
\hline & 2 & $0.79 \pm 0.06^{\mathrm{Ba}}$ & $1.03 \pm 0.04^{\mathrm{Aa}}$ & $1.04 \pm 0.01^{\mathrm{Ac}}$ \\
\hline & 3 & $0.79 \pm 0.06^{\mathrm{Ba}}$ & $1.08 \pm 0.04^{\mathrm{Ba}}$ & $1.38 \pm 0.14^{\mathrm{Ab}}$ \\
\hline & 4 & $0.79 \pm 0.06^{\mathrm{Ca}}$ & $1.03 \pm 0.01^{\mathrm{Ba}}$ & $1.32 \pm 0.01^{\mathrm{Ab}}$ \\
\hline \multirow{4}{*}{ pH } & 1 & $5.42 \pm 0.01^{\mathrm{Ba}}$ & $5.42 \pm 0.00^{\mathrm{Bb}}$ & $5.86 \pm 0.01^{\mathrm{Aa}}$ \\
\hline & 2 & $5.42 \pm 0.01^{\mathrm{Ca}}$ & $5.51 \pm 0.01^{\mathrm{Ba}}$ & $5.64 \pm 0.01^{\mathrm{Ab}}$ \\
\hline & 3 & $5.42 \pm 0.01^{\mathrm{Ca}}$ & $5.51 \pm 0.01^{\mathrm{Ba}}$ & $5.64 \pm 0.03^{\mathrm{Ab}}$ \\
\hline & 4 & $5.42 \pm 0.01^{\mathrm{Ba}}$ & $5.42 \pm 0.00^{\mathrm{Bb}}$ & $5.48 \pm 0.00^{\mathrm{Ac}}$ \\
\hline \multirow{4}{*}{$\begin{array}{l}\text { Total Nitrogen } \\
(\%)\end{array}$} & 1 & $3.53 \pm 0.05^{\mathrm{Ca}}$ & $3.91 \pm 0.05^{\mathrm{Ba}}$ & $4.63 \pm 0.16^{\mathrm{Aa}}$ \\
\hline & 2 & $3.57 \pm 0.12^{\mathrm{Ba}}$ & $3.91 \pm 0.08^{\mathrm{ABa}}$ & $4.10 \pm 0.07^{\mathrm{Ab}}$ \\
\hline & 3 & $3.59 \pm 0.01^{\mathrm{Ba}}$ & $3.89 \pm 0.04^{\mathrm{Aa}}$ & $3.94 \pm 0.00^{\mathrm{Ab}}$ \\
\hline & 4 & $3.60 \pm 0.01^{\mathrm{Ca}}$ & $3.83 \pm 0.06^{\mathrm{Ba}}$ & $4.08 \pm 0.10^{\mathrm{Ab}}$ \\
\hline \multirow{4}{*}{ WSN (\%) } & 1 & $0.11 \pm 0.01^{\mathrm{Ca}}$ & $0.56 \pm 0.02^{\mathrm{Ba}}$ & $0.99 \pm 0.04^{\mathrm{Aa}}$ \\
\hline & 2 & $0.11 \pm 0.01^{\mathrm{Ca}}$ & $0.49 \pm 0.03^{\mathrm{Ba}}$ & $0.69 \pm 0.03^{\mathrm{Ab}}$ \\
\hline & 3 & $0.11 \pm 0.01^{\mathrm{Ba}}$ & $0.58 \pm 0.04^{\mathrm{Aa}}$ & $0.63 \pm 0.01^{\mathrm{Ab}}$ \\
\hline & 4 & $0.11 \pm 0.01^{\mathrm{Ca}}$ & $0.57 \pm 0.03^{\mathrm{Ba}}$ & $0.68 \pm 0.00^{\mathrm{Ab}}$ \\
\hline \multirow{4}{*}{ TCA-SN (\%) } & 1 & $0.06 \pm 0.00^{\mathrm{Ba}}$ & $0.11 \pm 0.02^{\mathrm{Ba}}$ & $0.36 \pm 0.05^{\mathrm{Aa}}$ \\
\hline & 2 & $0.06 \pm 0.00^{\mathrm{Ba}}$ & $0.07 \pm 0.01^{\mathrm{ABb}}$ & $0.11 \pm 0.02^{\mathrm{Ac}}$ \\
\hline & 3 & $0.05 \pm 0.01^{\mathrm{Ba}}$ & $0.07 \pm 0.01^{\mathrm{Bb}}$ & $0.25 \pm 0.00^{\mathrm{Ab}}$ \\
\hline & 4 & $0.05 \pm 0.00^{\mathrm{Ba}}$ & $0.07 \pm 0.00^{\mathrm{Bb}}$ & $0.23 \pm 0.03^{\mathrm{Ab}}$ \\
\hline \multirow{4}{*}{ PTA-SN (\%) } & 1 & $0.01 \pm 0.00^{\mathrm{Ca}}$ & $0.05 \pm 0.01^{\mathrm{Ba}}$ & $0.09 \pm 0.00^{\mathrm{Aa}}$ \\
\hline & 2 & $0.01 \pm 0.00^{\mathrm{Ca}}$ & $0.03 \pm 0.00^{\mathrm{Bb}}$ & $0.05 \pm 0.00^{\mathrm{Ab}}$ \\
\hline & 3 & $0.01 \pm 0.00^{\mathrm{Ba}}$ & $0.02 \pm 0.00^{\mathrm{Bb}}$ & $0.03 \pm 0.02^{\mathrm{Ab}}$ \\
\hline & 4 & $0.01 \pm 0.00^{\mathrm{Ca}}$ & $0.03 \pm 0.00^{\mathrm{Bb}}$ & $0.06 \pm 0.00^{\mathrm{Ab}}$ \\
\hline \multirow{4}{*}{$\begin{array}{l}\text { ADV } \\
\text { (meq } 100 \mathrm{~g}^{-1} \text { fat) }\end{array}$} & 1 & $0.80 \pm 0.06^{\mathrm{Ba}}$ & $1.57 \pm 0.04^{\mathrm{Ba}}$ & $22.44 \pm 2.81^{\mathrm{Aa}}$ \\
\hline & 2 & $0.80 \pm 0.06^{\mathrm{Ca}}$ & $1.37 \pm 0.12^{\mathrm{Ba}}$ & $2.96 \pm 0.09^{\mathrm{Ac}}$ \\
\hline & 3 & $0.80 \pm 0.06^{\mathrm{Ba}}$ & $1.47 \pm 0.12^{\mathrm{Ba}}$ & $8.48 \pm 1.29^{\mathrm{Ab}}$ \\
\hline & 4 & $0.80 \pm 0.06^{\mathrm{Ca}}$ & $1.53 \pm 0.04^{\mathrm{Ba}}$ & $3.22 \pm 0.12^{\mathrm{Ac}}$ \\
\hline
\end{tabular}

a-c Different lowercase letters within a column and item indicate significant differences between cheese samples $(\mathrm{P}<0.05)$.

A-C Different uppercase letters within a row (sample) and item indicate significant differences between storage periods $(\mathrm{P}<0.05)$.

1: Control; 2: Sodium caseinate, 3: Sodium caseinate / Transglutaminase, 4: Chitosan.

Analysis of the data revealed a regular increase in acidity in all Kashar cheese samples used in the experiment, relative to the length of storage time that they underwent. However, the highest acidity value 
was obtained in uncoated cheese samples on both the 30th and 60th days of storage. These results indicate that coatings inhibit microbial activity both within the sample and on the sample surface by limiting oxygen transmission and forming a barrier against contamination. At the end of the storage period, the difference between acidity values of uncoated cheese samples and those of coated cheese samples was found to be statistically significant $(\mathrm{P}<0.05)$ (Table 1). Yangilar (2015), examining the acidity values of Kashar cheeses coated with casein and casein/natamycin-based edible films over a 90day storage period, found the highest acidity value in uncoated cheese samples, consistent with the results of our study. Similar results have also been reported by Di Pierro et al. (2011) and SoleimaniRambod et al. (2018).

The $\mathrm{pH}$ values of the Kashar cheese samples increased significantly during the storage period $(\mathrm{P}<0.05)$, with the highest $\mathrm{pH}$ value found in the uncoated samples (Table 1). This increase can be explained by mould growth. Moulds such as Penicillium roqueforti and P. camemberti, which may be used as starters for cheese or result from subsequent contamination, are both able to assimilate the acidic molecules in the medium as well as form buffering compounds by breaking down $\alpha$ s 1- and $\beta$-casein through the secretion of extracellular proteinases (McSweeney, 2004; Beuvier and Buchin, 2005). As uncoated cheeses yield more disintegration products because of microbial activity, the $\mathrm{pH}$ was significantly higher than in coated samples $(\mathrm{P}<0.05)$. While some studies have reported similar results, finding that uncoated cheeses had higher $\mathrm{pH}$ values compared to coated ones at the end of 90 days (Yangılar, 2015; Yangılar and Oğuzhan-Yıldız, 2016), others have observed only statistically insignificant differences in $\mathrm{pH}$ values between coated and uncoated cheeses (Di Pierro et al., 2011).

Total nitrogen values of all samples increased over time during the storage period, with the greatest increase following storage observed in the uncoated cheese samples and dry matter (Table 1). These do represent actual increases, however, but only proportional ones, occurring solely as a result of moisture loss.

Evaluating the samples for water-soluble nitrogen (WSN), trichloroacetic acid-soluble nitrogen (TCA-SN), and phosphotungstic acid-soluble nitrogen (PTA-SN) revealed increases in all these values, with the highest values obtained from uncoated samples during the storage period (Table 1).

Nitrogen fractions are indicators proteolysis, the most important biochemical process in cheese. With ripening, the amount of nitrogenous substances soluble in water increases in proportion to the degradation of proteins by microorganisms and enzymes. The level of nitrogen soluble in trichloroacetic acid indicates the presence of small-size peptides (> 20 AA residues) and amino acids. These amino acids and peptides are formed by the disintegration of peptides separated from casein by microbial enzymes as a result of rennet and plasmin activity, and are known as "the total maturation depth index". The nitrogen fraction soluble in phosphotungstic acid represents the sum of tri- and di-peptides as well as free amino acids consisting of casein and casein-derived peptides resulting from the activities of enzymes in starter and non-starter microorganisms (McSweeney and Sousa, 2000; McSweeney, 2004).

The statistically significant $(\mathrm{P}<0.05)$ increase in all three nitrogen fraction values for the uncoated and coated samples at the end of the storage period can be attributed to the intensive mould growth on the cheese surfaces. Although mould growth was observed on the surface of the coated cheese samples (Table 2), the coating materials partially prevented the surface microflora from affecting the cheese components. Consistent with our findings, Y1lmaz and Dağdemir (2012) reported that WSN values for Kashar cheese samples were statistically higher in uncoated samples on the 120th day of storage than for those coated with single or double layers of wax. Similar results also have been reported by Yangilar and Oğuzhan-Yıldız (2015) for Kashar cheeses coated with casein. 
Lipolysis in cheese occurs as a result of the natural lipoprotein lipase of milk, lipase from the starter or raw milk microflora, or esterase or pregastric esterases added to milk (Beuvier and Buchin, 2005). Lipolysis values for all Kashar cheese samples in the present study showed a significant increase $(\mathrm{P}<0.05)$ over time. Similar results have been reported by Soleimani-Rambod et al. (2018). However, increases in lipolysis values of the uncoated samples were statistically significantly $(\mathrm{P}<0.05)$ higher than those of the coated samples (Table 1). The reason for the higher lipolysis values of the uncoated samples compared to the coated ones can be explained by the fact that in the absence of a protective coating, microbial activity on the surface affects the cheese interior.

In a study investigating the effects of chitosan-based coatings prepared with oregano and rosemary oils on goat milk cheese, the cheese was ripened in cold conditions for 15 days. Lipolysis values for all samples increased over time, with the highest increases observed in the uncoated samples (Embuena et al., 2017). The highest lipolysis values after storage were obtained from the control group samples, similar to our results.

\section{Texture Profile Analyses (TPA)}

At all points of measurement during the storage period, the hardness values for all samples were higher than those at the beginning of storage $(\mathrm{P}<0.05)($ Table 2$)$.

Table 2. Results of some textural analysis and mould-yeast counts of Kashar cheese uncoated and coated with different edible films (mean \pm standard deviation)

\begin{tabular}{|c|c|c|c|c|}
\hline & \multicolumn{4}{|c|}{ Storage Period (Days) } \\
\hline & Sample & $\mathbf{0}$ & 30 & 60 \\
\hline \multirow{4}{*}{$\begin{array}{l}\text { Hardness } \\
\text { (g) }\end{array}$} & 1 & $1816.25 \pm 43.56^{\mathrm{Bd}}$ & $1423.85 \pm 25.95^{\mathrm{Cc}}$ & $2128.15 \pm 37.13^{\mathrm{Ac}}$ \\
\hline & 2 & $1989.84 \pm 15.80^{\mathrm{Cc}}$ & $2875.99 \pm 95.16^{\mathrm{Bb}}$ & $3996.95 \pm 25.67^{\mathrm{Ab}}$ \\
\hline & 3 & $2299.34 \pm 0.95^{\mathrm{Ca}}$ & $3900.30 \pm 307.02^{\mathrm{Ba}}$ & $5995.80 \pm 189.50^{\mathrm{Aa}}$ \\
\hline & 4 & $2154.78 \pm 63.96^{\mathrm{Cb}}$ & $3876.45 \pm 37.55^{\mathrm{Ba}}$ & $5950.70 \pm 69.30^{\mathrm{Aa}}$ \\
\hline \multirow{4}{*}{ Springiness } & 1 & $0.91 \pm 0.01^{\mathrm{Ba}}$ & $0.94 \pm 0.00^{\mathrm{Aa}}$ & $0.88 \pm 0.00^{\mathrm{Bb}}$ \\
\hline & 2 & $0.91 \pm 0.01^{\mathrm{Aa}}$ & $0.92 \pm 0.00^{\mathrm{Aa}}$ & $0.88 \pm 0.00^{\mathrm{Bb}}$ \\
\hline & 3 & $0.91 \pm 0.01^{\mathrm{ABa}}$ & $0.90 \pm 0.00^{\mathrm{Bb}}$ & $0.92 \pm 0.01^{\mathrm{Aa}}$ \\
\hline & 4 & $0.92 \pm 0.00^{\mathrm{ABa}}$ & $0.93 \pm 0.01^{\mathrm{Aa}}$ & $0.89 \pm 0.01^{\mathrm{Bb}}$ \\
\hline \multirow{4}{*}{ Cohesiveness } & 1 & $0.75 \pm 0.01^{\mathrm{Bc}}$ & $0.87 \pm 0.02^{\mathrm{Aa}}$ & $0.66 \pm 0.00^{\mathrm{Cc}}$ \\
\hline & 2 & $0.79 \pm 0.00^{\mathrm{Ab}}$ & $0.81 \pm 0.03^{\mathrm{Aa}}$ & $0.69 \pm 0.02^{\mathrm{Bb}}$ \\
\hline & 3 & $0.80 \pm 0.00^{\mathrm{ABab}}$ & $0.81 \pm 0.00^{\mathrm{Aa}}$ & $0.79 \pm 0.01^{\mathrm{Ba}}$ \\
\hline & 4 & $0.81 \pm 0.00^{\mathrm{ABa}}$ & $0.88 \pm 0.04^{\mathrm{Aa}}$ & $0.76 \pm 0.00^{\mathrm{Ba}}$ \\
\hline \multirow{4}{*}{$\begin{array}{l}\text { Chewiness } \\
\text { (g) }\end{array}$} & 1 & $1246.78 \pm 19.54^{\mathrm{Ac}}$ & $1171.98 \pm 4.65^{\mathrm{Bc}}$ & $1240.59 \pm 22.37^{\mathrm{Ad}}$ \\
\hline & 2 & $1444.24 \pm 31.49^{\mathrm{Cb}}$ & $2147.51 \pm 23.97^{\mathrm{Bb}}$ & $2437.71 \pm 71.93^{\mathrm{Ac}}$ \\
\hline & 3 & $1682.95 \pm 12.37^{\mathrm{Ca}}$ & $2841.10 \pm 224.94^{\mathrm{Ba}}$ & $4362.72 \pm 47.55^{\mathrm{Aa}}$ \\
\hline & 4 & $1606.62 \pm 48.90^{\mathrm{Ca}}$ & $3183.12 \pm 220.63^{\mathrm{Ba}}$ & $4047.44 \pm 104.97^{\mathrm{Ab}}$ \\
\hline \multirow{4}{*}{$\begin{array}{l}\text { Adhesiveness } \\
\text { (g.sn) }\end{array}$} & 1 & $76.13 \pm 8.49^{\mathrm{Aab}}$ & $52.93 \pm 16.07^{\mathrm{ABa}}$ & $18.40 \pm 7.99^{\mathrm{Ba}}$ \\
\hline & 2 & $84.93 \pm 7.47^{\text {Aab }}$ & $31.65 \pm 4.20^{\mathrm{Bab}}$ & $17.84 \pm 0.78^{\mathrm{Ba}}$ \\
\hline & 3 & $70.88 \pm 2.83^{\mathrm{Ab}}$ & $34.29 \pm 2.16^{\mathrm{Bab}}$ & $20.94 \pm 0.36^{\mathrm{Ca}}$ \\
\hline & 4 & $91.38 \pm 2.27^{\mathrm{Aa}}$ & $12.17 \pm 0.51^{\mathrm{Bb}}$ & $5.74 \pm 1.58^{\mathrm{Cb}}$ \\
\hline \multirow{4}{*}{$\begin{array}{l}\text { Mould-Yeast } \\
(\text { CFU Log10 g-1) }\end{array}$} & 1 & $1.10 \pm 0.12^{\mathrm{Ca}}$ & $4.84 \pm 0.00^{\mathrm{Bc}}$ & $7.13 \pm 0.04^{\mathrm{Aa}}$ \\
\hline & 2 & $1.10 \pm 0.12^{\mathrm{Ca}}$ & $5.45 \pm 0.21^{\mathrm{Ba}}$ & $7.01 \pm 0.03^{\mathrm{Ab}}$ \\
\hline & 3 & $1.10 \pm 0.12^{\mathrm{Ca}}$ & $5.71 \pm 0.08^{\mathrm{Bb}}$ & $6.85 \pm 0.05^{\mathrm{Ac}}$ \\
\hline & 4 & $1.10 \pm 0.12^{\mathrm{Ca}}$ & $4.70 \pm 0.11^{\mathrm{Ac}}$ & $4.00 \pm 0.00^{\mathrm{Bd}}$ \\
\hline
\end{tabular}

a-d Different lowercase letters within a column and item indicate significant differences between cheese samples $(\mathrm{P}<0.05)$.

A-C Different uppercase letters within a row (sample) and item indicate significant differences between storage periods $(\mathrm{P}<0.05)$.

1: Control, 2: Sodium caseinate, 3: Sodium caseinate /Transglutaminase, 4: Chitosan, CFU: Colony forming unit

However, the highest hardness values were obtained from samples in groups 3 and 4 . The samples coated with the edible film were found to have significantly higher hardness values than the uncoated control samples at all stages of the analysis period $(\mathrm{P}<0.05)$. This result can be linked to the reduced 
ripening of the coated samples. Since coatings inhibit the transfer of microorganisms from contaminated surfaces to the cheese interior, the ripeness level of the coated samples was lower than that of the control group, thus affecting the textural properties of the samples.

Consistent with the results of our study, Cerqueira et al. (2010) reported that the hardness values of semi-hard local cheeses coated with galactomannan and chitosan increased during storage in all samples, with the lowest hardness values obtained from uncoated samples stored at $+4{ }^{\circ} \mathrm{C}$. Sarığlu and Öner (2006) found that the internal and external hardness values of the control group samples were significantly higher than their coated counterparts as a result of excessive moisture loss in uncoated samples.

Springiness values for the Kashar cheese samples generally decreased during the storage period, with increases in springiness over time observed only in samples from group 3. The difference between the springiness values of the group 3 samples (coated with sodium caseinate/transglutaminase enzyme) and the other uncoated and coated samples at day 60 of storage was statistically significant $(\mathrm{P}<0.05)$ (Table 2). According to Kuraishi et al. (2017), the transglutaminase enzyme forms cross-links between protein molecules. In their study, the transglutaminase enzyme cross-linked the casein molecules used in the coating formulation to render the coating more flexible, leading to higher springiness values for the samples coated with this material. Similar to our results, Yaşar and Güzeler (2011) reported that the springiness values for Kashar cheese decreased to 0.70 from an initial value of 0.82 at the end of 90 days of storage.

The cohesiveness value determined by the textural profile analysis is a function of the interaction between the elements in the cheese mass and the tensile strength of the internal bonds forming the structure of the cheese. The cohesiveness values of the Kashar cheese samples for days 0, 30, and 60 are presented in Table 2. An increase in cohesiveness was observed in both uncoated and coated samples on the 30th day of storage, after which time cohesiveness decreased to below the initial values. Differences between cohesiveness values at the start and end of the storage period are statistically significant $(\mathrm{P}<0.05)$. The lowest cohesiveness values as a result of storage were obtained from uncoated cheese samples, the group in which the most ripening occurs (Table 1). The decline in cohesiveness can be attributed to a reduction in interactions and bonding between components in the cheese due to enzymatic and chemical reactions. The cohesiveness values for Kashar cheeses obtained following 90-day storage periods in studies by Sahan et al. (2008) and Yaşar and Güzeler (2011) are consistent with our results (0.75 - 0.69 and $0.76-0.67$, respectively).

The chewiness values of the control samples exhibited no significant changes at the end of the storage period compared to the initial values, whereas those of the coated samples showed significant increases $(\mathrm{P}<0.05)$ (Table 2). The lowest chewiness values as a result of storage were obtained from uncoated control samples; the differences between the groups were statistically significant $(\mathrm{P}<0.05)$. The cheeses coated with films produced from sodium caseinate/transglutaminase enzyme were found to have the highest chewiness values (Table 2). Chewiness refers to the energy required to chew solid food to the point of swallowing. The higher chewiness values of the coated cheeses may be explained by the lower maturation parameters in these sample groups and by the coatings forming a firm and flexible layer on the product surface. Due to cross-linking between the transglutaminase enzyme and the protein molecules, the coating material with this enzyme increased the flexibility of those cheeses, resulting in the highest chewiness values being obtained from this group. Koca and Metin (2004) reported chewiness values for Kashar cheeses determined at the beginning and end of a 90-day storage period of 3.21 and $3.42 \mathrm{~N}$, respectively, results with are generally consistent with those of the present study. 
Following the 60-day storage period, adhesiveness values for all samples showed significant decreases $(\mathrm{P}<0.05)$. Adhesiveness is defined as the force required to overcome the attractive forces between the surface of the food and the surface of other materials in contact with the food (e.g., tongue, teeth, palate). The decrease in surface adhesiveness of the samples can be attributed to the fact that the sample surfaces lose moisture over time, becoming drier. This may be due to fact that the microorganisms developing on both coated and uncoated samples - in particular, the yeasts and moulds hydrolysing the proteins on the surface - form an adhesive layer on the surface with the disintegration products they release. At the end of the storage period, the lowest surface adhesiveness values were obtained from cheeses coated with chitosan, a carbohydrate-based coating. Similarly, the yeast and mould counts were also lower In cheeses coated with chitosan-based film than for the other groups.

\section{Microbiological analysis (yeast and mould counts)}

Yeast and mould counts increased significantly during the storage period for all samples coated with casein and chitosan-based edible films as well as for uncoated Kashar cheese $(\mathrm{P}<0.05)$. The number of yeasts and moulds identified on samples coated with chitosan-based film alone decreased by approximately 1 log during the final period of storage compared to the previous analysis (Table 2). The differences between the yeast and mould counts of the samples on the 30th and 60th days of storage were also statistically significant $(\mathrm{P}<0.05)$. When the samples were examined in terms of yeast and mould count at the end of storage, the lowest numbers were obtained from the samples coated with chitosan (Table 2). This result indicates that chitosan, which has antimicrobial properties, limits the growth of yeasts and moulds on the cheese surface.

In a related study comparing certain properties of Kashar cheeses coated with sodium caseinate with uncoated control samples during 90 days of storage, no mould was detected in either of the groups. Y1lmaz and Dağdemir (2012) reported that wax coating on Kashar cheeses resulted in a $2.5 \log$ unit decrease in the mould counts compared to uncoated cheeses following 120 days of storage. At the end of storage, moulds were detected in control, single layer wax, double layer wax, and vacuum-packed samples at the level of $4.60 \pm 0.39,2.05 \pm 0.70,1.89 \pm 0.29,2.82 \pm 0.19 \log 10 \mathrm{CFU} / \mathrm{g}$, respectively. Yangilar (2015) found that chitosan and chitosan + whey protein-based coatings along with storage time had significant effects on the mould counts of Kashar cheeses $(\mathrm{P}<0.05)$, reporting that the mould counts of all samples declined 1 log after 90 days of storage. Yangılar and Oğuzhan-Yıldız (2015), however, observed the highest mould count in the control group samples following 90 days of storage in cheddar cheeses coated with casein, casein/natamycin, and natamycin. Only the mould counts of samples coated with casein/natamycin decreased below $1 \mathrm{log}$, whereas those of the other samples remained above this level. These results are generally consistent with the findings obtained in our study.

\section{CONCLUSION}

Surface desiccation and microbial contamination are the primary obstacles to maintaining the freshness of sliced or portioned Kashar cheeses. In this study, we hypothesized that these issues could be solved with the use of edible film coatings, which can regulate the interaction between food, packaging, and the environment, thus stabilizing food quality. The most important property of edible films is that they can act as barriers against moisture and oxygen. They can also serve as carriers for natural antioxidants and antimicrobial agents to protect food quality. According to the nitrogen fractions and lipolysis results obtained in our study, proteolysis and lipolysis levels for the uncoated samples were higher than those of the coated samples over a 60-day storage period. Determination of the highest dry matter values in uncoated samples showed that they lost more moisture than the coated samples, indicating that the coating materials used formed an effective moisture barrier. The lowest yeast and 
mould counts were found in the samples coated with chitosan, an expected result as it is a polymer with antifungal properties. Nitrogen fractions and lipolysis values for the coated samples were lower than those of the control samples, although surface moulds were observed in all samples, indicating that coatings were effective in preventing the passage of microorganisms onto the surface of the product. Textural analysis results showed that the lowest springiness, cohesiveness, and chewiness values were obtained from the control group samples, due to the higher levels of proteolysis and lipolysis occurring in this group. Our findings demonstrated that sodium caseinate, sodium caseinate/transglutaminase enzyme, and chitosan coatings were effective in preserving and maintaining the chemical, microbiological, and textural properties of sliced fresh Kashar cheese. However, moulds and contaminating microorganisms on the surface of the product were able to make use of the nutrients in the coating material in all sample groups. As the dipping process used in our study is likely to cause contamination, in order for such coatings to be effective and safe for consumption, proper methods to prevent contamination and provide an effective outer coating should be chosen. If solutions to these issues can be found, edible coatings can be used safely to preserve the quality of Kashar cheese served in slices.

\section{REFERENCES}

Ananey-Obiria D, Matthewsa L, Azahrania MH, Ibrahima SA, Galanakisb CM, Tahergorabia R, 2018. Application of protein-based edible coatings for fat uptake reduction in deep-fat fried foods with an emphasis on muscle food proteins. Trends in Food Science \& Technology, 80: 167-174. doi: 10.1016/j.tifs.2018.08.012.

AOAC, 2002a. Official Methods of Analysis of International. 17th. (no. 935.42) AOAC (Association of Official Analytical Chemists) International, Gaithersburg, Maryland, USA.

AOAC, 2002b. Official Methods of Analysis of International. 17th. (no. 2001.14) AOAC (Association of Official Analytical Chemists) International, Gaithersburg, Maryland, USA.

Artiga-Artigas M, Acevedo-Fani A, Martín-Belloso O, 2017. Improving the shelf life of low-fat cut cheese using nanoemulsionbased edible coatings containing oregano essential oil and mandarin fiber. Food Control, 76: 1-12. doi: 10.1016/j.foodcont.2017.01.001.

Barreto PLM, Pires ATN, Soldi, V, 2003. Thermal degradation of edible films Based on Milk Proteins and Gelatin in Inert Atmospher. Polymer Degradation and Stability, 79: 147-152. doi: 10.1016/S0141-3910(02)00267-7.

Beuvier E, Buchin S, 2005. Raw Milk Cheeses. In Fox PF, McSweeney PLH, Cogan TM, Guinee TP (Eds.), Cheese: chemistry, physics and microbiology,Volume 1, (pp. 319-345). UK: Academic Press.

Bütikofer U, Rüegg M, Ardö Y, 1993. Determination of nitrogen fractions in cheese: Evaluation of a collaborative study. LWT - Food Science and Technology, 26(3): 271-275. doi: 10.1006/fstl.1993.1056.

Carvalho RA, Grosso CRF, 2004. Characterization of gelatin based films modified with transglutaminase, glyoxal and formaldehyde. Food Hydrocolloid, 18: 717-726. doi: 10.1016/j.foodhyd.2003.10.005.

Cerqueira MA, Sousa-Gallagher MJ, Macedo I, Rodriguez-Aguilera R, Souza BWS, Teixeira JA, Vicente AA, 2010. Use of galactomannan edible coating application and storage temperature for prolonging shelf-life of "Regional" cheese. Journal of Food Engineering, 97: 87-94, doi: 10.1016/j.jfoodeng.2009.09.019. 
Chen H, 1995. Functional properties and applications of edible films made of milk proteins. Journal of Dairy Science, 78: 2563-2570. doi: 10.3168/jds.S0022-0302(95)76885-0.

Debeaufort F, Quezada-Gallo JA, Voilley A, 1998. Edible films and coatings: tomorrow's packagings: A review. Critical Reviews in Food Science and Nutrition, 38(4): 299-313. doi: 10.1080/10408699891274219.

Devlieghere F, Vermeulen A, Debevere J, 2004. Chitosan: antimicrobial activity, interactions with food components and applicability as a coating on fruits and vegetables. Food Microbiology, 21: 703714. doi: 10.1016/j.fm.2004.02.008.

Dhall RK, 2013. Advances in edible coatings for fresh fruits and vegetables: A rewiew. Critical Reviews in Food Science and Nutrition, 53(5): 435-450. doi: 10.1080/10408398.2010.541568.

Di Pierro P, Sorrentino A, Mariniello L, Giosafatto CVL, Porta R, 2011. Chitosan/whey protein film as active coating to extend Ricotta cheese shelf-life. LWT - Food Science and Technology, 44: 23242327. doi: 10.1016/j.lwt.2010.11.031.

Embuena AIC, Nácher MC, Boix AC, Pons MPM, Llopis MB, Martínez MCB, Martínez CG, 2017. Quality of goat's milk cheese as affected by coating with edible chitosan-essential oil films. International Journal of Dairy Technology, 70(1): 68-76. doi: 10.1111/1471-0307.12306.

Gennadios A, Hanna MA, Kurth LB, 1997. Application of edible coatings on meats, poultry and seafoods: A review. LWT - Food Science and Technology, 30(4): 337-350. doi: 10.1006/fstl.1996.0202.

Guillard V, Broyart B, Bonazzi C, Guilbert S, Gontard N, 2003. Preventing moisture transfer in a composite food using edible films: Experimental and mathematical study. Journal of Food Science, 68(7): 2267-2277. doi: 10.1111/j.1365-2621.2003.tb05758.x.

Hassan B, Chatha SAS, Hussain AI, Zia KM, Akhtar N, 2018. Recent advances on polysaccharides, lipids and protein based edible films and coatings: A review. International Journal of Biological Macromolecules, 109(1): 1095-1107. doi: 10.1016/j.ijbiomac.2017.11.097.

IDF, 2004. Cheese and Processed Cheese, Determination of the Total Solids Content (Reference Method). IDF 4: 2004(E) International Standart (second edition), Brussels, Belgium. www.iso.org/standard/35249.html

IDF, 1991. Routine Methods for Determination of Free Fatty Acids in Milk. Bulletin of the IDF. No. 265, p. 26-32.

Kang HJ, Jo C, Kwon JH, Kim JH, Chung HJ, Byun MW, 2007. Effect of a pectin-based edible coating containing green tea powder on the quality of irradiated pork patty. Food Control, 18(5): 430-435. doi: 10.1016/j.foodcont.2005.11.010.

Kaya S, Kaya A, 2000. Microwave Drying Effects On Properties Of Whey Protein Isolate Edible Films. Journal of Food Engineering, 43(2): 91-96. doi: 10.1016/S0260-8774(99)00136-3.

Koca N, Metin M, 2004. The textural, melting and sensory properties of low-fat fresh kashar cheese produced by using fat replacers. International Dairy Journal, 14(4): 365-373. doi: 10.1016/j.idairyj.2003.08.006.

Krasaekoopt W, Mabumrung J, 2008. Microbiological evaluation of edible coated fresh-cut cantaloupe. Natural Science, 42: 552-557.

Kuraishi C, Yamazaki K, Susa Y, 2007. Transglutaminase: it's Utilization in the food industry. Food Reviews International, 17(2): 221-246. doi: 10.1081/FRI-100001258.

Kürek M, Ščetar M, Galić K, 2017. Edible coatings minimize fat uptake in deep fat fried products: A review. Food Hydrocolloid, 71: 225-235. doi: 10.1016/j.foodhyd.2017.05.006. 
McSweeney PLH, 2004. Biochemistry of Cheese Ripening. International Journal of Dairy Technology, 57: 127-144. doi: 10.1111/j.1471-0307.2004.00147.x.

McSweeney PLH, Sousa MJ, 2000. Biochemical pathways for the production of flavour compounds in cheeses during ripening: A review. Le Lait, 80: 293-324. doi: 10.1051/lait:2000127.

Mizuno A, Mitsuiki M, Motoki M, 1999. Glass transition temperature of casein as affected by transglutaminase. Journal of Food Science, 64(5): 796-799. doi: 10.1111/j.13652621.1999.tb15914.x.

Moreira RM, Roura IR, Ponce A, 2011. Effectivenes of chitosan edible coatings to improve microbiological and sensory quality of fresh cut broccoli. LWT - Food Science and Technology, 44(10): 2335-2341. doi: 10.1016/j.lwt.2011.04.009.

Özdemir M, Floros JD, 2004. Active food packaging technologies. Critical Reviews in Food Science and Nutrition, 44(3): 185-193. doi: 10.1080/10408690490441578.

Peng Y, Han B, Liu W, Xu X, 2005. Preparation and antimicrobial activity of hydroxypropyl chitosan. Carbohydrate Research, 340(11): 1846-1851. doi: 10.1016/j.carres.2005.05.009.

Sahan N, Yasar K, Hayaloglu AA, Karaca OB, Kaya A, 2008. Influence of fat replacers on chemical composition, proteolysis, texture profiles, meltability and sensory properties of low-fat Kashar cheese. Journal of Dairy Research, 75(1): 1-7. doi: 10.1017/S0022029907002786.

Sánchez-Ortega I, García-Almendárez BE, Santos-López EM, Amaro-Reyes A, Barboza-Corona JE, Regalado C, 2014. Antimicrobial edible films and coatings for meat and meat products preservation. The Scientific World Journal, Article ID 248935: 1-18. doi: 10.1155/2014/248935.

Sarığlu T, Öner Z, 2006. Yenilebilir Filmlerin Kaşar Peynirinin Kaplanmasında Kullanılma Olanakları ve Peynir Kalitesi Üzerine Etkileri. G1da, 31(1): 3-10.

Schorsch C, Carrie H, Norton IT, 2000. Crosslinking casein micelles by a microbial transglutaminase: Influence of crosslinks in acid-induced gelation. International Dairy Journal, 10(8): 529-539. doi: 10.1016/S0958-6946(00)00069-8.

Shahidi F, Janak KVA, Jeon YJ, 1999. Food applications of chitin and chitosans. Trends in Food Science and Technology, 10(2): 37-51. doi: 10.1016/S0924-2244(99)00017-5.

Sharma R, Zakora M, Qvist KB, 2002. Characteristics of oil-water emulsions stabilised by an industrial $\alpha$-lactalbumin concentrate, cross-linked before and after emulsification, by a microbial transglutaminase. Food Chemistry, 79(4): 493-500. doi: 10.1016/S0308-8146(02)00225-X.

Simôes ADN, Tudela JA, Allende A, Psuchmann R, Gil MI, 2009. Edible coatings containing chitosan and moderate modified atmospheres maintain quality and enhance phytochemicals of carrot sticks. Postharvest Biology and Technology, 51(3): 364-370. doi: 10.1016/j.postharvbio.2008.08.012.

Soleimani-Rambod A, Zomorodi S, Raeisi SH, Khosrowshahi A, Seyed-Ahmad Shahidi SA, 2018. The effect of xanthan gum and flaxseed mucilage as edible coatings in cheddar cheese during ripening. Coatings, 8(2): 1-14. doi: 10.3390/coatings8020080.

Suppakul P, Miltz J, Sonneveld K, Bigger SW, 2003. Active packaging technologies with an emphasis on antimicrobial packaging and its applications. Journal of Food Science, 68(2): 408-420. doi: 10.1111/j.1365-2621.2003.tb05687.x.

Valenzuela C, Tapia ., Lopez L, Bunger A, Escalona V, Abugoch L, 2015. Effect of edible quinoa protein-chitosan based films on refrigerated strawberry (Fragaria $\mathrm{x}$ ananassa) quality. Electronic Journal of Biotechnology, 18(6): 406-411. doi: 10.1016/j.ejbt.2015.09.001. 
Vilela C, Kurek M, Hayouka Z, Röcker B, Yildirim S, Antunes MDC, Nilsen-Nygaard J, Pettersen MK, Freire CSR, 2018. A concise guide to active agents for active food packaging. Trends in Food Science and Technology, 80: 212-222. doi: 10.1016/j.tifs.2018.08.006.

Yangilar F, 2015. Chitosan/whey protein (CWP) edible films efficiency for controlling mould growth and on microbiological, chemical and sensory properties during storage of göbek Kashar cheese. Korean Journal for Food Science of Animal Resources, 35(2): 216-224. doi: 10.5851/kosfa.2015.35.2.216.

Yangılar F, Oğuzhan-Yıldız P, 2016. Casein/Natamycin edible films efficiency for controlling mould growth and on microbiological, chemical and sensory properties during the ripening of Kashar cheese. Journal of the Science of Food and Agriculture, 96(7), 2328-2336. doi: 10.1002/jsfa.7348.

Yasar K, Güzeler N, 2011. Effects of coagulant type on the physicochemical and organoleptic properties of Kashar cheese. International Journal of Dairy Technology, 64(3): 372-379. doi: 10.1111/j.14710307.2011.00679.x.

Yıldırım M, Güleç F, Bayram M, Yıldırım Z, 2006. Properties of Kashar cheese coated with casein as a carrier of natamycin. Italian Journal of Food Science, 18(2): 127-138.

Yilmaz F, Dağdemir E, 2012. The effect of beeswax coating on quality of Kashar cheese during ripening. International Journal of Food Science \& Technology, 47(12). 2582-2589. doi: 10.1111/j.13652621.2012.03137.x.

Zhong Y, Cavender G, Zhao Y, 2014. Investigation of different coating application methods on theperformance of edible coatings on Mozzarella cheese. LWT - Food Science and Technology, 56(1): 1-8. doi: 10.1016/j.lwt.2013.11.006. 